\title{
Forest Protection Policies
}

National guidelines and their local implementation in northern Sichuan

\section{Sylvie Démurger, Martin Fournier and Guozhen Shen}

\section{(2) OpenEdition}

\section{Journals}

Electronic version

URL: http://journals.openedition.org/chinaperspectives/481

DOI: 10.4000/chinaperspectives.481

ISSN: 1996-4617

\section{Publisher}

Centre d'étude français sur la Chine contemporaine

\section{Printed version}

Date of publication: 1 June 2005

ISSN: 2070-3449

\section{Electronic reference}

Sylvie Démurger, Martin Fournier and Guozhen Shen, «Forest Protection Policies », China Perspectives [Online], 59 | may - june 2005, Online since 29 November 2006, connection on 28 October 2019. URL: http://journals.openedition.org/chinaperspectives/481 ; DOI : 10.4000/chinaperspectives.481

This text was automatically generated on 28 October 2019

(c) All rights reserved 


\title{
Forest Protection Policies
}

\author{
National guidelines and their local implementation in northern Sichuan \\ Sylvie Démurger, Martin Fournier and Guozhen Shen
}

\section{EDITOR'S NOTE}

Translated from the French original by Jonathan Hall

This study is part of a multidisciplinary programme entitled "Protection of forest resources and the well-being of the rural population: comparative case studies in China". It is funded by the French ministry in charge of Research into New Technologies within the programme Action Concertée Incitative (ACI) "Societies and cultures in sustainable development". We are especially grateful to Professor Li Junqing of the Peking Forestry University, for his invaluable help in enabling our field work.

China has a total area of 175 million hectares of forestland (fifth in terms of size in the world), and a standing timber stock volume of 12.5 million cubic metres (which ranks it number seven). Yet despite these figures, its timber resources remain relatively scarce ${ }^{1}$. Its wooded areas represent only $4 \%$ of the world's total, and its standing timber accounts for only $3 \%$ of the world's reserves ${ }^{2}$. Its forest cover stands at $18.21 \%$ of the total land mass, which is slightly over half of the world average, but only $0.13 \%$ hectares per capita, which is well below the world average of $0.65 \%$. Finally, its standing stock is also very low, at less than 10 cubic metres per capita, whereas the global average is 66 cubic metres.

2 The forest deficit that characterises China today is the outcome of a long history of deforestation, which became particularly acute after the founding of the People's Republic. Forest resources declined in both quantity and quality between 1958 and 1982, particularly during three periods of intense deforestation. The first of these coincided with the launch of the Great Leap Forward (1958-1961). It led to the felling of thousands of hectares of trees to supply the furnaces for steel production, and without any attempt at replanting. The second period followed the nationwide implementation of the policy of self-sufficiency in grain from the late 1960s onwards, and the 
generalisation of the Dazhai model which favoured the use of terraced land. This decision to encourage the expansion of agricultural land at the expense of other land uses, taking no account of natural local conditions, resulted in a new wave of intense deforestation throughout the country ${ }^{3}$. Finally, when the household responsibility system was extended to forested land in the early 1980s, a large number of peasants, fearing that the policy on land use might change again, immediately took advantage of the land contracted out to them and cut down the trees ${ }^{4}$.

3 The Chinese government has come to appreciate the ecological consequences of this deforestation, and of the increasing pressure on the ecosystem by the growing demand for timber products 5 . Over the last twenty years it has radically changed its policy on forest regions, from a strategy based on production and exploitation to one of protection of resources and conservation of biodiversity. In this article we propose to give an account of the protection programmes introduced at the national level, and to analyse their impact on the rural population. We will present a comparative study of three townships in Sichuan province, based on a series of interviews held in November 2004 with cadres from the localities and the forestry administration.

Forest protection policiesThe principal phases

Over the last sixty years, the conservation of China's forestry resources has followed the twists and turns in the political and economic decisions of the leadership. As in the case of the decisions concerning the exploitation of these resources, three distinct phases in their conservation can be identified. During the first of these, lasting until the late 1960s, several attempts at protecting the forests and their biodiversity were made by the government, despite the heavy demand for timber. The most notable of these was the creation of nature reserves. The first nature reserve (Dinghushan) was set up in 1956 in Guangdong province, followed in October of the same year by a plan to designate specific zones as national nature reserves. In the following decade, nineteen nature reserves were established, covering around 650 thousand hectares (Table 1). 
The development of protected zones in China

\begin{tabular}{|c|c|c|c|}
\hline & $\begin{array}{l}\text { Number } \\
\text { of nature } \\
\text { reserves }\end{array}$ & $\begin{array}{r}\text { Surface area } \\
\left(\mathrm{km}^{2}\right)\end{array}$ & $\begin{array}{l}\text { Percentage } \\
\text { of the total } \\
\text { land mass } \\
\text { of the country }\end{array}$ \\
\hline 1956 & 1 & 11 & -- \\
\hline 1965 & 19 & 6,489 & 0.07 \\
\hline 1978 & 34 & 12,650 & 0.13 \\
\hline 1982 & 119 & 40,819 & 0.40 \\
\hline 1985 & 333 & 193,300 & 2.10 \\
\hline 1987 & 481 & 237,000 & 2.47 \\
\hline 1989 & 573 & 270,630 & 2.82 \\
\hline 1990 & 606 & 400,000 & 4.00 \\
\hline 1991 & 708 & 560,666 & 5.54 \\
\hline 1993 & 763 & 661,791 & 6.89 \\
\hline 1995 & 799 & 719,067 & 7.49 \\
\hline 1997 & 926 & 769,790 & 8.02 \\
\hline 1999 & 1,146 & 881,524 & 8.80 \\
\hline 2000 & 1,227 & 982,080 & 9.90 \\
\hline 2001 & 1,551 & $1,298,900$ & 12.90 \\
\hline 2002 & 1,757 & $1,329,450$ & 13.20 \\
\hline 2003 & 1,999 & $1,439,800$ & 14.40 \\
\hline
\end{tabular}

Source: China Statistical Yearbook, Peking, China Statistics Press.

5 However these protection efforts were interrupted during the Cultural Revolution, and the development of nature reserves stagnated until the 1980s. In the context of the selfreliance policy, the mountain regions which actually enjoyed a comparative advantage for the exploitation of forestry resources, were nonetheless cleared in order to develop a scarcely viable plan for cereal production. For over ten years forest protection was neglected, and even the natural self-regeneration of the forests was thwarted by the extension of agricultural land.

6 Finally, from the 1980s onwards, there arose a new realisation of the need to protect both forestry resources and the environment, inspiring a series of laws and regulations, along with the establishment of different institutions to implement them. At the same time, systematic efforts were made to document and preserve the existing biodiversity ${ }^{6}$, and to set up stricter controls over access by rural communities to natural resources in non-agricultural areas. The 1992 UN Rio Conference on the Environment and Development was also a major step in committing the Chinese authorities to establish a process of "sustainable development", according to which any exploitation of resources should meet current needs without harming future generations ${ }^{8}$.

7 The rapid growth in the number of nature reserves testifies to this process of instilling an awareness among the Chinese people of the need to protect the environment. This has been reinforced by a programme for raising consciousness at the national level through the development of ecological tourism in the protected areas. By the end of 2003, the number of listed reserves stood at 1,999, covering a total area of 144 million hectares, which is $14.4 \%$ of the total land mass of the country (Table 1 ).

8 The policy of intensive exploitation of forestry resources, which was implemented over nearly half a century, has led to a serious deterioration in national resources ${ }^{9}$, bringing 
in its wake major ecological risks such as soil erosion, floods, droughts, desertification, loss of biodiversity and ecological inheritance, as well as a decrease in the availability of drinking water. In particular, the cultivation of marginal (formerly wooded) sloping low yielding land is the underlying cause behind the huge problems of soil erosion in Western China, where over $70 \%$ of cultivated land on slopes over 25 degrees are to be found ${ }^{10}$. Out of the two million tons of silt carried out to sea by the Yangtse and Yellow Rivers each year, two thirds are thought to be due to such agricultural practices ${ }^{11}$. This silt has been a major cause in the formation of alluvial banks in the lakes and reservoirs, and in raising the river beds, leading to the recurrent water-related disasters (floods, droughts etc.) in the Yangtse and Yellow River basins. In addition, rural communities present a further threat to non-agricultural land through their exactions upon its resources (for firewood, grazing land etc.), thus endangering the natural environment and the self-renewal of the forests. It was because of this situation that in the late 1990s the Chinese government set up a "new forest policy" ${ }^{12}$ which brought together two large-scale programmes: the first aimed at the protection of natural forests (tianranlin ziyuan baohu gongcheng), and the second at the conversion of agricultural land into forests or grasslands (tuigeng huanlin huancao). The implementation of these programmes was prompted by two unprecedented major ecological catastrophes, the drying of the Yellow River in 1997, and the flooding of the Yangtse in $1998^{13}$.

The natural forest protection programme

The natural forest protection programme was launched in two pilot zones in 1998, and extended in 2000 for a projected eleven-year period. It was aimed at reducing the annual production of commercial timber to 20 million cubic metres, which is a third of the 1998 volume. Its three main provisions are : the prohibition, or severe limitation, on felling in the state-owned natural forests in the 17 provinces bordering the two main rivers, and in other vulnerable areas ${ }^{14}$; the reforestation of hillsides and barren land, as well as the proper upkeep of forest lands ; and a restructuring of the stateowned forestry industry ${ }^{15}$. The prohibitions on felling affect thirty million hectares of natural forests around the upper reaches of the Yangtse, and around the middle and upper reaches of the Yellow River. This represents a little over a fifth of the forested areas of the country as a whole.

10 Sichuan province, which has around $10 \%$ of China's natural forests, implemented the programme in August 1998, starting in five prefectures and extended later to all of its counties. The restrictions which were imposed as part of the programme applied in the first instance to commercial felling in the natural forests, which was immediately halted. In order to reinforce this prohibition, from September 1999 the transportation of wood was also forbidden, and the regional sawmills and wood processing enterprises were forced to shift their focus (onto tree planting or forestry management).

11 However the restrictions on felling were gradually relaxed after 2000, in order to lessen the negative impact of these programmes on the local populations. The main governmental measure in this regard was to draw up a classification, specifying which forests could be exploited and which could not. This policy change was managed by the local forestry bureaus (linye ju) at the different levels (from the provincial down to the village level). The new classification distinguishes between three categories : ecological forests (where all restrictions are rigorously applied), commercial forests (where some kinds of felling are tolerated), and firewood forests ${ }^{16}$. The aim is to allow a new form of 
exploitation of forest resources in the so-called commercial forests, taking account of both the demand for timber products (mainly for the construction industry) and the needs of the local ecology. To achieve these ends, the Chinese government rents out certain areas of so-called "demonstration" land to households or commercial enterprises, to be used as commercial forests ${ }^{17}$.

The sloping land conversion programme

The sloping land conversion programme was initiated in 1999 in three pilot provinces (Gansu, Sha'anxi and Sichuan), and was gradually extended to 25 provinces (and 2,000 counties) ${ }^{18}$. Like the natural forest protection programme, it is centred mainly on the regions along the Yangtse and Yellow Rivers. The aim of this ambitious programme is to reduce soil erosion by reconverting more than 14 million hectares of cultivated land, including 4.4 million hectares on slopes over twenty-five degrees ${ }^{19}$. In Sichuan, this affects 770,000 hectares ${ }^{20}$. By the end of 2004, 7.86 million hectares had been reconverted ${ }^{21}$. By its sheer magnitude, it is the world's largest conversion programme, and its aim is to put an end to an ancestral Chinese practice of sloping land cultivation ${ }^{22}$.

In order to support peasant incomes, the Chinese government participates in this conversion programme by providing subsidies both in kind (grain and seedlings) and in cash, lasting over a period of eight years if the land is converted into ecological forests, and over five years in the case of commercial forests ${ }^{23}$. The subsidies in kind vary according to region and are higher in the provinces on the upper reaches of the Yangtse than in those on the upper reaches of the Yellow River. They range from an annual 1,500 to 2,250 kilos of grain per hectare (200 to $300 \mathrm{jin}$ per $\mathrm{mu}$ ). In addition the peasants receive an annual cash compensation of 300 yuan per hectare (20 yuan per $\mathrm{mu})$ as well as free seedlings at the time of the conversion, with a standard quality equivalent of about 750 yuan per hectare (50 yuan per $\mathrm{mu})^{24}$. By the end of 2003, the total subsidies distributed through this policy had reached 5.56 million yuan, and the quantity of grain supplied to the peasants was 16.53 million tons. There are 17.58 million rural households who have benefited from these measures ${ }^{25}$.

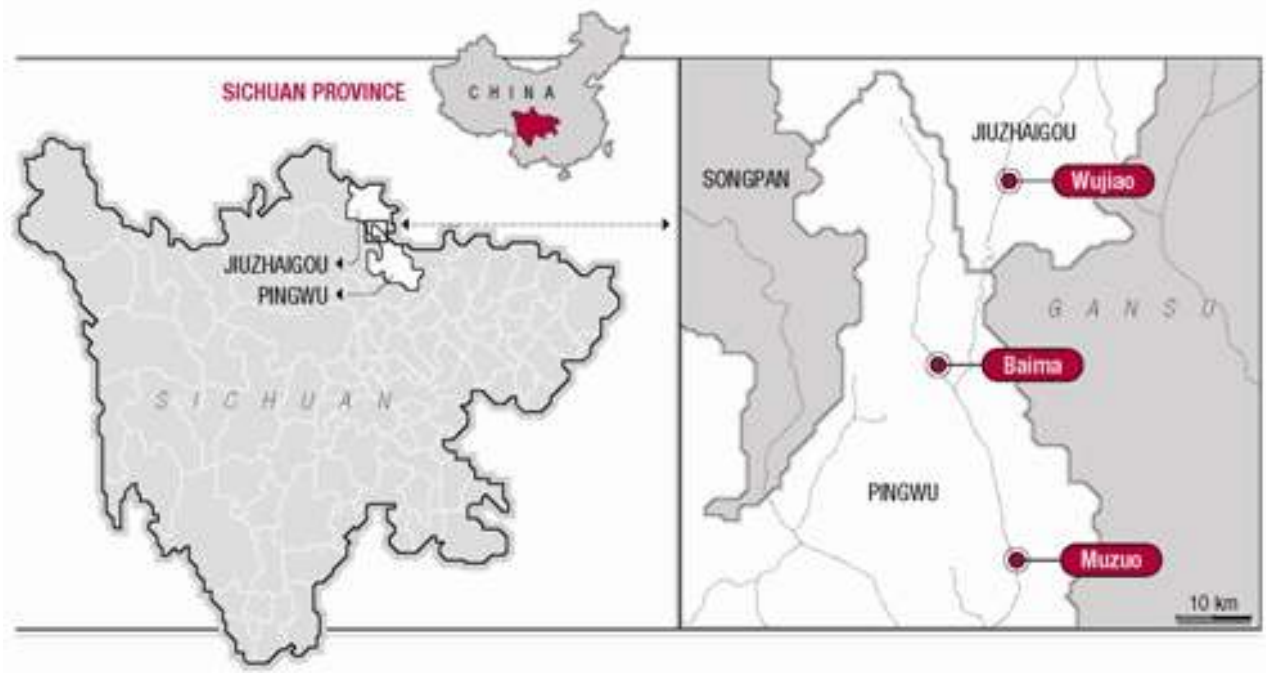

The Muzuo, Baima and Wujiao townships in northern Sichuan

Our research into the local implementation of the national forest protection policies is based on a series of interviews, conducted in November 2004, with officials from the county forestry administrations and township leaders (or Party secretaries). The area 
covers three townships in two counties in Sichuan province, namely Muzuo and Baima in Pingwu county, which is 300 kilometres north of Chengdu, and Wujiao in Jiuzhaigou county, which is 150 kilometres north of Pingwu (on the border of Gansu province). Situated in the Min mountain range, in the northern part of the province ${ }^{26}$, these three townships have in common a largely Tibetan population, which represents over half of the population of Muzuo and Wujiao, and the whole population of Baima (see Table 2).

The area formed by these three townships is crucial for the conservation of biodiversity and the protection of rare animal species. Pingwu county in particular has the largest concentration of giant pandas in the world, but their habitat is inadequately protected because it is fragmented by areas of human occupation ${ }^{27}$. The area covered by the present study constitutes a vital corridor within the Min mountain range for these animals, since it links three nature reserves: Wanglang to the north of the Baima township (established in 1965), Wujiao (established in 2001), and Baishuijiang, in Wen county (Gansu province). The fact that these different protected areas are linked by a single corridor places a strict limit on genetic exchange between the divided animal communities, putting the species themselves at risk. The reduction and fragmentation of the giant pandas' habitat is a major factor in the rapid decline in their numbers in the region ${ }^{28}$.

2- General features of the townships covered by this study

\begin{tabular}{l|r|r|r|}
\hline & \multicolumn{1}{|c}{ Muzuo } & \multicolumn{1}{c}{ Baima } & Wujiao \\
\hline County & Pingwu & Pingwu & Jiuzhaigou \\
\hline Distance from Chengdu & $330 \mathrm{~km}$ & $360 \mathrm{~km}$ & $450 \mathrm{~km}$ \\
\hline Number of villages & 3 & & 5 \\
\hline $\begin{array}{l}\text { Number of village groups } \\
\text { (zui) }\end{array}$ & 13 & 15 & 15 \\
\hline Overall population (2004) & 1,640 & 1,506 & 2,256 \\
\hline number of Tibetans included & 980 & 1,506 & 1,400 \\
\hline $\begin{array}{l}\text { Households engaged } \\
\text { in agriculture (\%) }\end{array}$ & 40 & 83 & 71 \\
\hline $\begin{array}{l}\text { Altitude at centre } \\
\text { of township (metres) }\end{array}$ & 1,000 & 2,048 & 1,900 \\
\hline $\begin{array}{l}\text { Area of township (km²) } \\
\text { Land area under cultivation } \\
\text { (ha) }\end{array}$ & 476 & 715 & 230 \\
\hline $\begin{array}{l}\text { Forested land area } \\
\text { (ha) }\end{array}$ & 13 & 50 & 79 \\
\hline including natural forests (ha) & 26,667 & & \\
\hline $\begin{array}{l}\text { Area of converted land } \\
\text { (ha) }\end{array}$ & 247 & 247 & 333 \\
\hline
\end{tabular}

Source: intervieus with township leaders and officials from the Pingurs

and Jituzhaigou forestry bureaus, November 2004.

16 In the three township areas, the commercial exploitation of the forests and the expansion of agriculture have become a threat to biodiversity. For over fifty years logging has been a major activity, and the consequent deforestation is the result of a situation which combines a lack of local economic opportunities with policies fomenting an expansion of agriculture without any corresponding local benefits, and a heavy dependence on commercial forestry. This has meant that the local populace 
depends to a large extent on forestry resources, not only for commercial exploitation ${ }^{29}$ but also for more traditional daily-life uses, like collecting firewood, gathering nonwood products, and grazing.

Before the establishment of the protection and conversion programmes, the three townships drew a considerable part of their revenue from forestry, and to a lesser extent, from agriculture ${ }^{30}$. The hilly nature of the region and the cramped nature of the cultivated land, even when it is terraced, do not in fact favour the development of highyield agriculture. All three townships used to engage in logging and selling the timber through their forest farms ${ }^{31}$. In addition, Muzuo and Baima had a number of sawmills. Thus the implementation of the natural forest protection programme has had a heavy impact on the local economy, since these activities were all cut short, the sawmills were closed, and the forest farms were reorganised for the purposes of protection and the prevention of fires ${ }^{32}$.

Being situated in a mountainous region with sloping ground, these three townships have few opportunities to develop any new economic activities which would allow their populations to escape poverty. For example, they have no rural industries, and the only non-agricultural activities which have been developed recently are linked to tourism (but on a very small scale), and to building dams (but these enterprises are managed from outside the village level and, in some instances, only employ labourers from other localities). This means that such productive activities as there are remain essentially related to agriculture (maize, potatoes, and various vegetables) and livestock (pigs, cattle, and sheep).

Local implementation of the national programmes

While the directives concerning the different programmes are decided centrally, their practical application can vary according to locality. In order to assess the effectiveness of the national policies, and their impact on local populations, it is useful to begin with a look at the ways in which they are applied locally. In the light of the type of programmes being launched, three important questions emerge: how are the restrictions on wood cutting applied, how is cultivated land converted, and how effective are the local measures for control and enforcement.

The restrictions on wood cutting

There are clear differences between the three townships, in their definition of places where collecting firewood is permitted, and in their response to the restrictions laid down nationally ${ }^{33}$. With regard to firewood collection sites, these fall into two main categories : the wood is gathered either in the collective forests managed by the village or village groups $(\mathrm{zu})$, or else in privately run woodlands (ziliushan) allocated to the peasants in the early $1980 \mathrm{~s}^{34}$.

In the first case, forest resources as a whole remain under collective control and the peasant households are allowed to gather wood in places specified by the townships ${ }^{35}$. However field observation shows that the rules are implemented differently in the different townships and villages, sometimes with rather lax interpretations of the users' rights, and an openly tolerant attitude towards those who overstep the mark, recalling the sad fate of the tragedy of commons. This is especially striking in certain villages in the Baima township, where villagers forage in the nearby collective forest, and where the local authorities effectively recognise illegal commercial logging by failing to impose any penalties. In these villages, the natural forest protection 
programme has clearly had no repercussions on the individual collection of firewood, since no restrictions have been applied, even on paper.

The private plots of forest land ${ }^{36}$ were distributed to households (or to different groups of households belonging to the same family) in 1982-1983. This form of ownership is to be found in the Muzuo township (in the villages of Xingyi and Heping), where there is an average of ten $m u$ of woodland per person. The households are permitted to gather as much firewood as they like, but they are required to seek permission to cut wood for other purposes (mainly for building). In addition, since 2002 they have had to observe a restriction on the thickness of the wood (it must not exceed 15 centimetres in diameter), and they are not allowed to collect firewood outside their own allocated plot. Unlike the situation in those villages where wood is gathered in the collective forests, in these villages restrictions appear to be more stringent. In addition to the imposition of the new measure controlling the thickness of the firewood, it is apparent from several interviews that the plot boundaries are clearly defined and well known to the villagers, and that they obey the rules which have been in force for over twenty years.

As for local reactions to the restrictions on gathering wood, the main changes are to be observed in the township of Wujiao. Here the conjoined effect of the natural forest protection programme and the establishment of a nature reserve in 2001, has had a greater impact on the practices of wood collection than in the other townships. Formerly each household possessed a plot of private woodland of 10 to $15 \mathrm{mu}$, and regulations similar to those in Muzuo were applied. But since 1998 this system has been revised, and the authorised sites for collecting wood have been transferred to the collective forests managed by village groups, situated in three valleys off the main road (Pingwu-Jiuzhaigou). Since the forests authorised for wood collection are no longer in the neighbourhood of the villages, the collection costs have increased considerably, due to the distances involved and the time needed to make the trip ${ }^{37}$. The increased distances have also weighed particularly heavily on elderly households, for whom such trips can be excessively long and arduous ${ }^{38}$. Finally, to the real costs involved in collecting wood should be added in some cases a downward pressure on supply. The three valleys involved in the cutting of firewood do not provide sufficient quantities for all of their households, and the latter are also subject to constraints on the thickness of the logs (less than 10 centimetres) and on the amount permitted (about 3 cubic metres per household).

The conversion of cultivated land

In the three townships, the policy for converting cultivated land has been implemented through directives from above. The overall amount of land scheduled for conversion is decided annually by the Sichuan forestry bureau, which allots quotas to the county offices, which in turn allot quotas to each village. The village leader then distributes the quotas among the households, each household being free to choose the plot to be converted and the species of trees to be planted. Since 2000, in Pingwu and Jiuzhaigou counties, nearly all the cultivated sloping land has been converted, representing areas of 100,000 $\mathrm{mu}$ and 66,000 $\mathrm{mu}$ respectively. Some households have converted all their land, while others still keep a few plots under cultivation. This is particularly the case in the Wujiao township, where each household still cultivates between 1 and $1.5 \mathrm{mu}$. In addition, field observation shows that in a number of converted plots, there is mixed cultivation, in which the planting of chestnut trees, firs, and peach trees, is combined 
with vegetables and lettuces, allowing the villagers a subsistence level of agricultural production.

Unlike the natural forest protection programme, the conversion programme was greeted favourably by the local population, for different but interconnected reasons. The first of these is due to the relatively generous subsidies granted to the households. In many cases the former annual yield from the converted land had been considerably lower than the subsidies ${ }^{39}$. Shen Maoying, from the Sichuan Academy of Social Sciences, has calculated that in certain townships of northern Sichuan, the gain was $30 \%$ higher than income from agricultural production ${ }^{40}$. In the three townships in the present study, average maize yields are low, both on slopes and level ground, being 150 kilogrammes per $m u$ in Wujiao, 200 to 225 kilogrammes in Baima, and 300 to 400 kilogrammes in Muzuo. The level of the peasants' support for the conversion reflects the difference in the yields of the three townships. For example, in Baima most peasants show a greater interest in converting than in cultivating, which is not the case in Muzuo. Moreover this feeling has been reinforced by supplementary adjustments in the villagers' favour by the local authorities. In the three townships, although a part of the converted land had not been formerly cultivated, several $m u$ of this already wooded land were retroactively attributed to the peasants by the local government. In some cases the number of $m u$ distributed in this way allowed the households to double their holdings in converted land, and consequently the amount of compensation received. Finally, by freeing up a part of the agricultural labour force, the programme has enabled the households to diversify their activities, to enter into the generally more lucrative non-agricultural sector, and so to increase their income.

Despite the favourable response to the land conversion policy, some aspects of its implementation have tended to highlight the weaknesses of the programme as conceived by the central authorities. For instance, failures to pay out adequate compensation have increased as the programme has expanded ${ }^{41}$. In the Wujiao township some families have not received compensations matching the number of $m u$ converted, particularly in the case of recent conversions, where there has been the equivalent of $1 \mathrm{mu}$ in subsidy for every 2 converted. In addition the quality of the stock for replanting has not always been adequate to maintain the required survival rate of $85 \%$ of replanted trees ${ }^{42}$. In the Baima township, for example, most of the inhabitants do not use the plants supplied by the government, because they are in poor condition (and sometimes even dead). Instead they are obliged to search for plants in the mountains for themselves.

The means of control and enforcement

One approach to assessing the effectiveness of the protection measures is to compare the provisions made to ensure respect for the restrictions involved (the number of forest wardens, the responsibilities assumed by the different levels of the administration) and to apply the necessary sanctions (the number of offences reported and the penalties imposed, the heaviness of those penalties). The tacit acceptance of illegal cutting, or other infractions related to the use of forest resources, varies from one township to another, and so does the imposition of penalties (Table 3). 
3- Offenses and means for enforcing restrictions

\begin{tabular}{|c|c|c|c|}
\hline & Muzuo & Baima & Whiliao \\
\hline $\begin{array}{l}\text { Number of offenses } \\
\text { reported in } 2003\end{array}$ & A few & $20-30$ & 2 \\
\hline Type of offense & Cutting for firewood & $\begin{array}{l}\text { Logging, transport } \\
\text { and sale of timber }\end{array}$ & Cutting for firewood \\
\hline $\begin{array}{l}\text { Number of forest wardens } \\
\text { (including part fime) }\end{array}$ & 30 & $4-8$ & 80 \\
\hline Number of penalties imposed & 1 & 20 & 2 \\
\hline Type of penalty & Fine ( 1,000 yuan $)$ & $\begin{array}{r}\text { Fine }(1,000 \text { to } 2,000 \text { yuan) } \\
+ \text { contiscation of toots }\end{array}$ & Fine (200 yuan) \\
\hline $\begin{array}{l}\text { Overt tolerance } \\
\text { of offences }\end{array}$ & " & yes & yes \\
\hline
\end{tabular}

The number of forest wardens employed in surveillance depends upon which administrative organisations are involved. In Wujiao township, there are two forest wardens appointed by each village, plus 34 employed by the nature reserve and 23 from the forest farm, making a total of about 80 for the whole township. The provision of such means is markedly lower in the other two townships, where only the local government is in charge. In the Baima township, for example, there are only one or two people from each village, employed on a part-time basis, to ensure observance of the rules, and the Muzuo township has a total of 30 people employed in surveillance.

The penalties are mostly financial (the amount of the fine is calculated according to the market value of the timber, usually multiplied by a factor of 3 or 4), but they also include confiscation of the tools used, and a court order to replant trees (in Wujiao the replanting must amount to 10 times the number cut down). In more serious cases, the culprits may be punished directly by the forestry security bureau.

There has been no report of major offences over the last three years in any of the three townships. On the other hand, a certain number of minor infringements have come to the authorities' attention, and have in some cases been punished. But here too there have been marked differences between the townships. In Wujiao no major offence was reported in 2003 or 2004, and only minor infringements (mainly concerning firewood collection) were reported between 1998 and 2003, leading to penalties not exceeding 200 yuan. In Baima, by contrast, about twenty offences were reported in 2003, mostly involving illegal logging, transport and sales. The majority of the offenders were punished by a fine of between 1,000 and 2,000 yuan, plus confiscation of tools (any unpunished offences being those where the offenders could not be identified). Finally, in the Muzuo township, several offences were reported for 2003 and only one was punished by a fine of 1,000 yuan.

There is a large gap, which varies according to the township concerned, between the control mechanisms put in place and the number of offences actually reported and punished. So, in Wujiao township, where serious measures have apparently been taken to ensure the implementation of the restrictions, no offence has been reported over the last two years. In this township, the village group leader is also responsible for what happens under his watch, and he is liable for punishment under the Forest Law in the case of any offence. Given these circumstances, the question of the effectiveness of the controls inevitably arises : is the absence of reported offences the result of effective control or a sign of its ineffectiveness? The Baima township presents the opposite case, in which the control mechanisms are apparently weaker but the number of reported offences is the highest. Unlike the two other townships, the Baima authorities also 
tolerate the existence of illicit trafficking, part of which concerns timber for sale. They justify this laxity in terms of the inhabitants' poverty.

It is obviously difficult to assess precisely to what extent the offences receiving punishment, and the seriousness of such punishments, are signs of any real differences in effectively limiting the number of offences. Nonetheless, field observation seems to suggest that Baima's low level of commitment to enforcement is linked to a low risk of punishment, and therefore to a higher level of offences, particularly in the field of massive logging for commercial use. By contrast, Wujiao's high level of commitment to control seems to limit the offences to isolated incidents of wood cutting for personal use.

How local people adjust to the restrictions

The launching of the protection and conversion programmes in the three townships has been accompanied by a series of shifts in the peasant households' modes of production and consumption. The initial negative impact upon the local populace caused by the natural forest protection programme in particular, has diminished over time, because villages and households have been able to turn to alternative sources of energy and of income. However, these shifts vary from place to place.

Wood collection and diversification of energy supplies

With regard to energy, the restrictions on cutting firewood have led the villages and households to seek ways to reduce their dependence on wood. Their adopted strategies vary in different townships, but they consist mainly in modernising equipment in order to save energy and/or developing means of using alternative sources of energy.

In the Baima township, unlike in the other two townships, households rely solely on wood for heating and cooking, and there are no plans to use any other source of energy. Nonetheless, when the restrictions were imposed, the township granted subsidies to the households to encourage the use of newer, more efficient stoves, in order to conserve energy. In addition, the households turned towards collecting wood from smaller trees and bushes.

In the other townships, the use of alternative energy supplies is contributing towards a reduction in dependency on firewood, even though this still remains the main source. The inhabitants of Muzuo township use electricity, as well as straw. And in the longer term, the building of dams close to the township promises to enable the electricity supply to be expanded. But it is in the Wujiao township that the greatest efforts towards energy diversification have been undertaken, with the encouragement of the local authorities, so that since 1998 the consumption of wood has indeed fallen. The inhabitants use more electricity and have adopted more efficient (dilu) heating, having been supported in these initiatives by aid from the government and the World Wildlife Fund (WWF). The main innovation in this respect has been locally produced biogas (zhaoqi). Experiments in the production of biogas, financed by the WWF and the Sichuan forestry bureau, are being carried out in some villages in the Wujiao township, and currently involve 17 households ${ }^{43}$. Pig raising enables these households to produce their own gas and use less wood, even though they continue to gather some wood because the systems cannot produce at full capacity in the winter months.

The conversion of arable land and the diversification of economic activity

The diversification of productive activities varies according to local conditions, and particularly in respect of the comparative advantages in each village. In the Muzuo and Wujiao townships, the conversion of land has enabled the agricultural labour force to 
be freed for other activities, so that in many households one member is engaged in non-agricultural pursuits ${ }^{44}$ either within the township area or else as a migrant labourer. In Muzuo local employment opportunities are provided by the hydroelectric dams being built, and in Wujiao by tourism related to the Jiuzhaigou nature reserve $e^{45}$. As for migration, there are certain patterns common to both townships (see Table 4): young migrants mainly seek to increase the household income by leaving to find jobs in tourism, building, or transport, either in the county or in the provincial cities (Chengdu in particular), but also in places like Shenzhen, Zhuhai, Peking, Guangzhou etc. ${ }^{46}$. Average wages earned by migrants from Muzuo are between 300 and 800 yuan per month, and by those from Wujiao, between 500 and 600 yuan.

\section{4- Migratory patterns}

\begin{tabular}{|c|c|c|c|}
\hline & Mursio & Baima & Wujiao \\
\hline Length of migration & $>1$ year & A few months & $>1$ year \\
\hline Employment & $\begin{array}{l}\text { Hotels, construction } \\
\text { transport }\end{array}$ & Transports, burism & Construction \\
\hline \multicolumn{4}{|l|}{ Migrant characteristics } \\
\hline Age & $30-40$ years & Young & Under 30 years \\
\hline $\operatorname{sex}$ & Men and women & Mostly men & Mostly men \\
\hline Educational level & Primary / secondary & Primary / secondary & Primary / secondary \\
\hline Main motives for migration & To increase incorne & . & To increase income \\
\hline Monthly wage scales & $300-800$ yuan & $500-600$ yuan & $500-600$ yuan \\
\hline
\end{tabular}

Baima is in a slightly different situation, since that township has developed its own tourist industry. However, this has not developed very far as yet, so less than $20 \%$ of the households have a member who is not employed in agriculture. In addition, there is relatively little migration from this township. The migrants, mostly young men, only stay away for a few months, working in transport or tourism-related activities (e.g. as Tibetan folklore singers and dancers in Mianyang, the capital city of the prefecture level).

Although Baima's local tourist industry is still largely undeveloped, it does offer a real alternative to traditional agricultural labour. Since 2000, fifty households have opened family hotels, providing a total of 2,000 beds, with the support of the central government, the WWF, and the European Union. In the same period, the township has also received subsidies for certain tourist-related projects (such as clean-ups after tourist visits, tree planting, and improvements to roads and rivers). The villages of Yazhe and Eli receive their own subsidies from Mianyang to improve the environmental conditions for tourism. In the two other townships, tourism remains undeveloped, with a 30-bed family hotel opening in Muzuo in 2002, and five small family hotels providing 5 to 6 beds each in Wujiao.

Apart from migrant labour and the development of tourism, some efforts have been made towards injecting dynamism into local agriculture and encouraging environmentally friendly forms of production. In Baima, the imposition of the restrictions was accompanied by measures aimed at helping the villagers to move away from established activities into vegetable growing. Currently 295 out of the 326 households (i.e. 90\%) are growing organic vegetables for the market. For this they underwent training financed jointly by the WWF Integrated Conservation and Development Project and the township administration, along with subsidies for the 
seedlings. In addition, since 2002 private companies from Mianyang have been renting land and using it for commercial agricultural production, thus providing jobs for some villagers. In Wujiao a similar policy has been instituted, enabling the households to market their produce (mostly cauliflowers) in Chengdu.

With the establishment of the natural forest protection programme, some townships have modified their grazing practices. In Baima, grazing is still practiced on open land, whereas in Muzuo it has become largely confined to enclosures. With the onset of the restrictions, households have received financial support from the county to develop different rearing methods. In Wujiao, grazing is restricted to certain sites, particularly in high mountain areas, and households have received financial aid from the township and the county, to improve their installations for raising pigs (applicable to households with more than five pigs). Within the nature reserve, grazing is forbidden, and the government has purchased all the animals from households affected by this prohibition.

In an overall situation where there are very few opportunities for getting out of poverty, it is important to try to assess the impact of public policies. Through our case study of these three rural townships in northern Sichuan, we have tried to throw light on the issues and the constraints affecting the national programmes for forest and biodiversity protection in China. Above all, our comparison of the different examples shows that the actual implementation of national policies can vary quite substantially from township to township-and indeed, even from village to village-, owing to the very wide variation in local economic and institutional circumstances. Our analysis of the two programmes in question highlights the difficulties of setting up a sustainable policy for protecting forest resources, and the key role of the government in their implementation.

With regard to the natural forest protection programme, we have found a wide range of means whereby restrictions on cutting wood (mostly for firewood) are imposed on households, varying according to the predominant form of ownership rights. Wherever the forest is essentially under collective ownership, rights and restrictions appear the most loosely defined, and the laxity of the authorities is most blatant. Conversely, where there are privately owned plots, the restraints seem to be at their strongest. Moreover it is in these same villages that the greatest efforts have been made towards diversifying the sources of energy, and in the poorest of them there has been strong local authority involvement, aimed at helping the villagers through this transformation.

As for the conversion of cultivated land, our comparative study has shown that there is greater uniformity in its implementation, but nonetheless with varying responses to the changes in economic activity, most of which are determined by relative local advantages. Here it is important to stress the essential role played by public financing in bringing about changes in behaviour. The populations under study in this article, who are mainly Tibetan and extremely poor, face the problems of having very little land to till, of needing to shoulder the burden of school fees for their children, and of encountering very few opportunities for earning any extra income. Given this predicament, both villagers and local authorities greeted the land conversion policy in a positive way, because the compensation in cash and grain was extremely welcome. Nonetheless, in view of the short term nature of the subsidies (from five to eight years), the question of its durability cannot be avoided. 


\section{NOTES}

1. Data from the sixth survey on China's forest resources, conducted between 1999 and 2003 (China Daily, January 19th 2005).

2. Food and Agriculture Organisation, The State of the World's Forests 2003, Rome, FAO, 2003.

3. Judith Shapiro, Mao's War against Nature: Politics and Environment in Revolutionary China, Cambridge University Press, 2001.

4. James Harkness, "Recent Trends in Forestry and Conservation of Biodiversity in China", The China Quarterly, No. 156, December 1998, pp. 911-934.

5. Total wood consumption in China reached a new peak of 228 million cubic metres in 2003 (China Daily, January 19th 2005).

6. Harkness, op. cit.

7. Michael Palmer, "Environmental Regulation in the People's Republic of China : The Face of Domestic Law", The China Quarterly, No. 156, December 1998, pp. 788-808.

8. Until that date, the Chinese government had favoured a markedly more accommodating position, giving preference to economic development, whatever the ecological cost.

9. Official statistics, particularly from the Maoist period, do not allow precise assessment of the extent of over-exploitation of the forests. Nonetheless, certain estimates at the county level clearly reveal drastic reductions in forest cover, ranging from $30 \%-50 \%$ in some places down to only $10 \%$ in others. Most of this logging was carried out on slopes subsequently abandoned because of erosion. See Richardson, S. D., Forests and Forestry in China - Changing Patterns of Resource Development, Island Press, Washington D. C., 1990, p. 22.

10. Xu Jintao, Eugenia Katsigris, and Thomas A. White, Implementing the Natural Forest Protection Program and the Sloping Land Conservation Program : Lessons and Policy Recommendations, China Council for International Cooperation on Environment and Development (CCICED), Task Force on Forests and Grasslands, Peking, China Forestry Publishing House, 2002.

11. Xu, Katsigris, White, op. cit.

12. Zhang Peichang, Guofan Shao, Guang Zhao, Dennis C. Le Master, George R. Parker, John B. Dunning, and Qinglin Li, "China's Forest Policy for the 21st Century", Science, Vol. 288, No. 5474, June 23rd 2000, pp. 2135-2136.

13. The Yellow River dried up for 267 days in 1997, a historical record (Xu, Katsigris, White, op. cit.). The floods in 1998 were also notable for their duration, the extent of the devastated area (one third of the overall area of the country), and the very high human and material losses.

14. The complete prohibition covers the provinces of the upper and middle reaches of the Yangtse (Tibet, Yunnan, Sichuan, Chongqing, Guizhou and Hubei) and of the Yellow River (Qinghai, Gansu, Ningxia, Inner Mongolia, Sha'anxi, Shanxi and Henan).

Reductions on felling in the state-owned forests cover the northeastern provinces (Jilin and Heilongjiang) as well as Hainan and Xinjiang.

15. This third set of measures is essentially "social", being aimed at facilitating the prospective re-employment of workers laid off by the state forestry enterprises, and at 
providing retirement benefits. The number of people directly affected by this programme is reckoned to be between 0.75 and 1.5 million.

16. In these forests, firewood is usually taken from bushes and shrubs which recover rapidly.

17. This policy is not uniformly applied throughout the territory. It is not applied, for instance, in the three townships of this present study, in which the commercial exploitation of the forests remains strictly forbidden.

18. Xu Zhigang, Michael T. Bennett, Ran Tao, and Jintao Xu, "China's Sloping Land Conversion Program four years on : current situation, pending issues", International Forestry Review, Vol. 6, Nos. 3-4, December 2004, pp. 317-326.

19. The programme also includes the conversion of uncultivated barren land.

20. Loucks Colby J., Zhi Lu, Eric Dinerstein, Hao Wang, David M. Olson, Chunquan Zhu, and Dajun Wang, "Giant Pandas in a Changing Landscape", Science, Vol. 294, No. 5546, November 16th, 2001, p. 1465.

21. China Daily, October 15th 2004. By the end of 2003 the amount of converted land stood at 6,196 million hectares, of which half had been cultivated (China Forestry Statistical Yearbook, 2003, p. 68).

22. World Wildlife Fund (2003), Report suggests China's 'Grain-to-Green' plan is fundamental to managing water and soil erosion, http ://wwfchina.org/english/loca.php ?loca=159

23. Ye Yanqiong, Chen Guojie, and Fan Hong, "Impacts of the 'Grain for Green' Project on Rural Communities in the Upper Min River Basin, Sichuan, China", Mountain Research and Development, Vol. 23, No. 4, November 2003, pp. 345-352.

24. Uchida Emi, Jintao Xu, and Scott Rozelle, "Grain for Green : Cost-effectiveness and Sustainability of China's Conservation Set-aside Program", mimeo, 2004.

25. China Forestry Statistical Yearbook 2003, p. 68.

26. The centre of the Muzuo township is at an altitude of 1,000 metres, and those of Baima and Wujiao are at 2,000 metres. Elevation differences vary between 900 and 4,125 metres.

27. See Loucks et al., op. cit.

28. Li An, Lupi Frank, Liu Jianguo, Lindeman Marc A., and Huang Jinyan, "Modelling the choice to switch from fuelwood to electricity : Implications for giant panda habitat conservation", Ecological Economics, Vol. 42, 2002, pp. 445-457.

29. For example, in 1997 81\% of the households in Baima, and 83\% in Muzuo, drew over half of their annual income from forest activities. See Chen Linwu, Xiang Chenghua, Liu Xingliang, and Mu Kehua, "The NFPP in Li and Pingwu Counties and Chuanxi Forestry Bureau, Sichuan Province", in Katsigris Eugenia, Xu Jintao, and Schmitt Ulrich (eds.), Implementing the Natural Forest Protection Program and the Sloping Land Conversion Program : Case Studies, China Council for Cooperation on Environment and Development (CCICED) Task Force on Forests and Grasslands, Peking, China Forestry Publishing House, 2004, pp. 3-39.

30. In 1997 forestry activities provided three quarters of total revenue for the townships of Muzuo and Baima. See Chen et al., op. cit.

31. Before 1998, local state enterprises and forest farms conducted the following operations : measuring trees for logging, logging, marketing, and regeneration. As these enterprises were controlled by the local government, the income from their sales went to the county which paid the wages. In most cases, their employees were local peasants, working part-time for the forest farms.

32. Chen et al. op. cit. 
33. In the framework of the natural forest protection programme, other prohibitions are also in force, particularly those aimed at hunting and lighting fires. Nonetheless, the restrictions which affect the villagers the most are those dealing with wood cutting. 34. The local expression for places where wood collecting is permitted is chaishan (literally mountains of firewood). The chaishan may be private, as in Muzuo, or collective, as in Wujiao.

35. In Wujiao township, the forestry bureau participates in deciding where wood collecting is allowed. This bureau also issues permits for cutting timber for building (no such permit was granted in 2003 and 2004).

36. However, in the last resort the land belongs to the collective, but the households may make use of it for sixty years (the length of the contract), and the contract may be passed on to their inheritors. They also have property rights on replanted land.

37. For example, the collection area for the village of Yangshan (Wujiao township) is 10 kilometres from the village.

38. Nonetheless, in certain townships there are regulations allowing the relaxation of these restrictions in the case of elderly inhabitants. Each villager over 60 receives 50 yuan per month to buy wood or pay other villagers who collect wood for them. This subsidy is paid by the county.

39. Xu, Katsigris, White, op. cit.

40. Interview, November 22nd 2004.

41. This weakness in the programme is also emphasised in the case of other regions by Uchida, $\mathrm{Xu}$, Rozelle, op. cit., and by Xu, Bennett, Tao, Xu, op. cit.

42. The conversion contracts, signed by the households and the township authority, stipulate that the survival rate in the plantations must exceed $85 \%$, or $70 \%$ in the high plateaus, mountainous areas, uplands, or barren or warm valleys. If this condition is not fulfilled, the township authority may suspend that year's compensation and only renew it when the survival rates meet the established criteria.

43. Installation costs per family are around 2,000 to 3,000 yuan. They include the purchase of a pig and the necessary fixtures (enclosure, pipeline etc.).

44. This is the case for all the households in the Muzuo township, and for half of them in Wujiao.

45. $80 \%$ of those employed in non-agricultural jobs in Wujiao work in the hotels and restaurants of Jiuzhaigou.

46. In Wujiao township, the migrants are mostly young (under 30); it is the men who tend to find work as unskilled labourers on building sites.

\section{ABSTRACTS}

This article compares three rural townships in northern Sichuan to assess the challenges and the constraints affecting China's national forest protection and biodiversity conservation programmes. It highlights the importance of the local economic and institutional environment for the ways in which it affects the implementation of national directives, giving rise to a wide variety of local responses. Our analysis of the natural forest protection programme and the 
sloping land conservation programme shows both the difficulties in launching a sustainable policy to protect the forests, and the strategic role of the government in ensuring their implementation. 